\title{
40-year Development of Ecologically Conscious Architecture in Slovakia
}

\author{
KRIŽÁNKOVÁ Alžbeta ${ }^{1, a^{*}}$ \\ ${ }^{1}$ Faculty of Architecture, Slovak University of Technology, Námestie slobody 19, 81245 Bratislava, \\ Slovakia \\ akrizankova.alzbeta@gmail.com
}

Keywords: sustainable architecture, ecology, Slovakia, architecture development

\begin{abstract}
The year 1973 was a breakthrough year in the development of architecture. It triggered a crisis in society as well as the end of a period of relative prosperity and wasting of energy, which until then did not constitute a limiting factor. The crisis has forced to seek a new and more efficient architecture. The following decades were each in their own way characteristic particular in how architects approached to reduce the energy consumption of buildings and how they resolved the relationship of the building to the surrounding and the environment at all. This paper maps ecological ideas in architecture in Slovakia on the background of broader context.
\end{abstract}

\section{Introduction}

The second half of the 20th century has brought number of changes to Slovak architectural scene. Changed economic and political conditions in the country after 1989 were the significant stimulus. Abroad forming thoughts and movements focusing on reducing the energy consumption of buildings and on friendly relationship with the environment, have reached our territory with a slight delay. Over time designers acquired these ideas and implemented them in their designs.

Now, let me briefly introduce the broader global context, providing the foundation for the whole idea of current sustainable design. The oil crisis in 1973 was the strongest stimulus for re-evaluation and a re-assessment of the previous energy wasting building concepts. It triggered the need to seek for alternatives in construction, introduction of austerity measures and a new and more efficient architecture.

Years following the oil crisis immediately until the early 80 s can be described as the period of searching. First of all it was about finding new sources of energy, which would have been a substitute for fossil fuels. The ambient energy and renewable energy sources has become an alternative to fossil fuels. Solar energy, as the main energy source for building performance has taken dominant position. Reducing the energy consumption of buildings has been achieved either by passive solar house design, such as architectural concept and efficient use of energy delivered to the system or through the application of active solar system in terms of solar collectors. Requirements on the effectiveness of the solar technologies, such as the slope and orientation, had an essential impact on the form and expression of nascent solar architecture.

Second decade could be defined from the early 1980s until 1992. Global threat of depletion of energy and mineral resources as well as environmental crisis has been still current, though not imminent. Architects therefore generally sought to design architecture that would have been less dependent on energy. A significant progress has meant the use of solar energy, especially by passive methods and by a holistic approach to architectural design. While in the first decade architects, designers and engineers struggled with various technical problems, in this period the building technologies and procedures were improved. Thus sustainable architecture could have been understood more comprehensive.

Globally, years 1992 and 1993 represent significant milestones of sustainable architecture development. These years allocate the beginning of the third decade. In 1992 two essential events happened. Situation regarding the environment led to the United Nations Conference on Sustainable 
Development in Rio de Janeiro. The second event was the European Congress of the International Union of Architects (UIA) on Eco-logical architecture in Stockholm and Helsinki. The next UIA World Congress was held in Chicago in 1993. The issue of liability of architects in relation to sustainable development has been discussed and a document the Declaration of Interdependence for a Sustainable Architecture has been adopted here in which sustainable architecture was officially recognized. Previous deviancy has become a trend in the development of architecture.

While the previous three decades were characterized by designing and building environmentally conscious architecture, the fourth decade, which began roughly with the new millennium is about the necessity to be concerned about sustainability. General trend known as sustainable development occurs. It seeks to face the global problems and challenges continuing from the previous periods. Development of sustainable architecture continues through both the architectural design and through the ongoing world conferences, appropriate documents and standards, European Union strategies, recommendations of Architectural Council of Europe (ACE), charters and directives. One of the most important documents adopted at the European level is the European Directive on the Energy Performance of Buildings 2010 as part of the 20-20-20 strategy, which obliges to design passive or nearly zero energy buildings.

Brief characteristic of the broader context provides an overview of the most important events and ideas forming the development of sustainable architecture. Each of the four decades are in more details described in the first part of our paper Our 20-year Long Journey Towards Meeting the Objectives of the European Strategy for Year 2020, published in the journal of last year's conference in Naples, which focused on environmental design for innovation in the post-crisis world. [1]

The ideas of sustainable architecture design reflected from the worldwide events to the Slovak architectural scene. However their enforcement is noticeable with a certain time delay.

\section{Beginning of Ecologically Conscious Architecture}

Neither the oil crisis nor the reports of depletion of mineral resources have not been taken very seriously in our country initially. The reason consisted in a different political situation than in industrialized countries and all the threats mentioned were considered to be the crisis of capitalism. Thus saving of energy was not needed. Over time, thoughts of environmental design from abroad have been acquired by several of our architects and enthusiasts. In the first decade, until the early 80s discussions of informal groups of intellectuals have been organized. They began to deal with the issue of energy efficiency, use of alternative energy sources and the environmental situation and sought to draw attention to the imminent crisis of energy and resources. Another group was formed by enthusiasts who practiced alternative lifestyle and building style. All ongoing activities were however just theoretical. First elements of ecologically conscious design were implemented to study tasks proposed by the Association of Slovak Architects, e.g. use of solar energy in the design of a city hotel (architects I. Matušík and I. Matušík Jr., 1981) or use of solar energy for recreational purposes (authors F. Zeman, P. Návrat, 1981). These were also just experimental projects, none of which was realized. The publication Solar Energy and Its Use elaborated under the leadership of professor M. Halahyja and published by Alfa publishing house in 1983 was the first tangible result of this period. It was the first publication on the issue of ecologically conscious architecture in Czechoslovakia.

\section{More Complex Understanding of Sustainable Architecture}

In the early 1980s, the interest focused mainly on the sun as an alternative source of energy. The following period has therefore experienced a more realistic development of environmentally conscious architecture in Slovakia. Several solar and experimental projects were designed, which aimed to reduce the energy consumption of the building through the use of solar energy. Methods applied were appropriate shape and spatial solution supporting low energy consumption, use of energy from the environment, return to the use of local materials and building traditions and later 
the use of active solar systems, which have been transforming solar energy through solar collectors. Mastering technical problems and reconciliation of more applicable methods triggered the rise of greater number of architectural projects striving for a sustainable design approach.

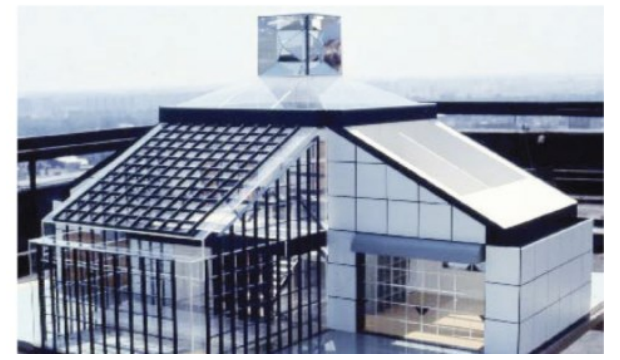

Fig. 1, Project of Experimental family house, designed in 1984 for the Agrokomplex Nitra exhibition to promote the use of alternative energy sources. [3] Architects J. Bóna, J. Keppl, R. Špaček

Some projects were designed for a specific customer, e. g. Multipurpose facility for the use of solar energy for Elektrosvit in Nové Zámky (1986) or Experimental family house designed for the Agrokomplex Nitra exhibition (Fig. 1) (architects J. Bóna, J. Keppl, R. Špaček, 1984) [3]. Slovak architects took part also in domestic and international architectural competitions, e.g. Energyefficient residential building in Pécs (architects D. Klein, P. Komár, M. Bogár, 1989). Other projects were the outcomes of research projects, such as the Low-energy solar house in Košice (Fig. 2), (architects J. Keppl, V. Šteffl, 1998) [4]. All of these projects have had common signs of ecologically conscious architecture. Those are, besides the methods mentioned above, the protruding glazed areas, sloping roofs or facades and their appropriate orientation towards the cardinals in order to capture the greatest amount of sunlight. Despite the fact that all of these projects remained unbuilt, they meant a significant progress for architecture of the 1980s while presenting real prospects of sustainable architecture.
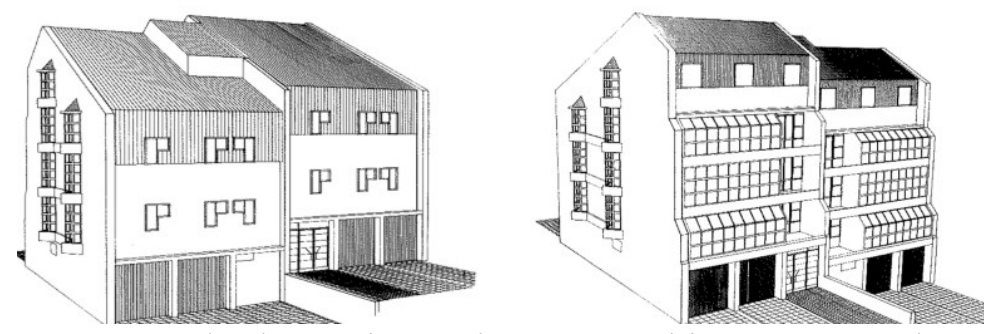

Fig. 2, Projects of Low-energy solar house in Košice. [4] Architects J. Keppl, V. Šteffl

One of the first built Slovak sustainable houses were designed by architect L. Kušnír. First Experimental residential house was built in 1987 in Valtice (Fig. 3). The aim of the experiment was to verify the properties of the new building system and the energy savings of the proposed facilities for active and passive use of solar energy, thus complex energy savings. New compositions of outer walls have been tested from the thermal insulation aspect, as well as new constructions of window openings, concept of ventilation of dwellings using windows recovery units, thermo-reflective wallpapers with the ability to reflect the thermal radiation and many others. [5] [6]

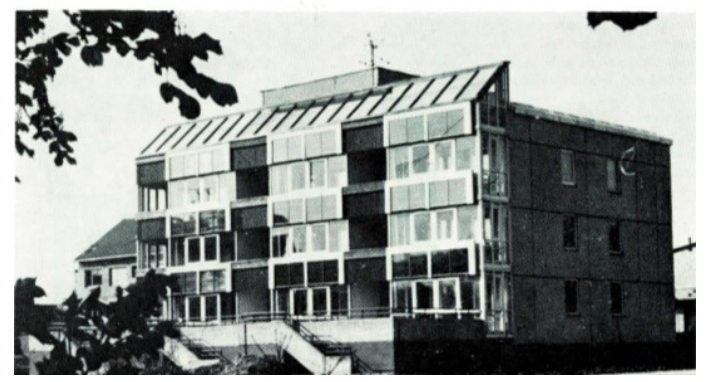

Fig. 3, Experimental residential house in Valtice. [5] Architects L. Kušnír, I. Jankovich, M. Vanek 
The second Experimental apartment building designed by architect L. Kušnír and his coworkers was completed in 1991 in Holíč (Fig. 4). Here, the successful elements of experimental house from Valtice were applied. The aim of this experiment was to verify floor heating system in dwellings by heat gained from the solar collectors. An appropriate architectural shape and concept, such as sloping of the southern part of the building with protruding greenhouses corresponded to its solar concept. Both apartment buildings were built to verify the non-conventional elements and their impact on the expression of architectural design. While the apartment building in Valtice was not intended to be a prototype for future residential solar architecture, the house in Holíc was meant to be a prototype of a residential building for rural settlement structures. [5] [6]
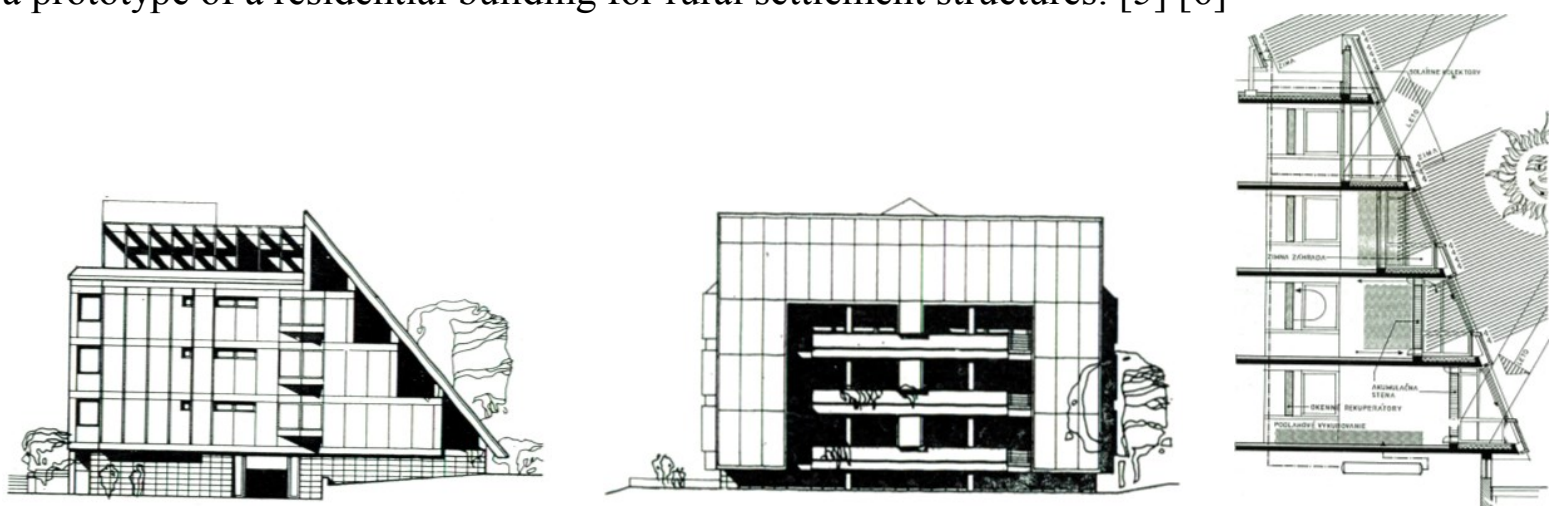

Fig. 4, Experimental apartment building in Holíč. [6] Western elevation, Southern elevation, Section. Architects L. Kušnír, M. Kiaček, B. Hnát, I. Kubík

Among the architectural design of family houses, the Solar house in Levice designed by architect Š. Drapčat (1990) (Fig. 5) is worth to mention. The location of the house on the southern slope allowed using both active and passive solar systems by shaping, inclination, orientation and materials used. Solar collectors provided hot water for both the house and the pool, located within the building. [7]

\section{From the Periphery to the Centre of Interest}

The change of political situation in our country has had an significant impact on the 1990s architectural design in Slovakia. After 1989 a number of interesting ecologically conscious projects has been designed. The new situation facilitated access to information, allowing to derive ideas and solutions from abroad, where the sustainable design was far more progressive. In Slovakia several projects have started, following the national and international interests, such as the international project of Brundtland City, which aimed at reducing energy consumption by half by 2030. The town of Rajec was selected for this project among other Slovak applying towns.

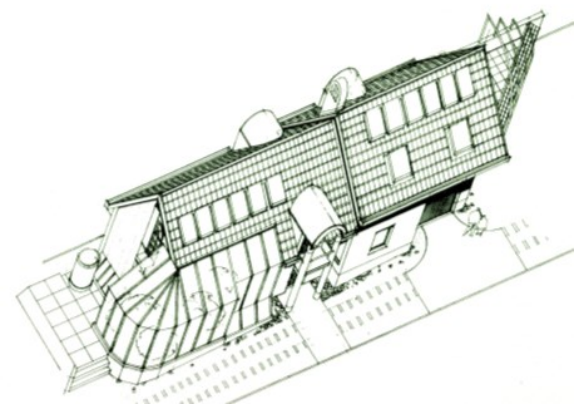

Fig. 5 , Solar single family house in Levice. [7] Architect Š. Drapčat

Continuing from previous decades, the aim of sustainable design to reduce energy consumption of the buildings, particularly through the use of solar energy proceeds. Thanks to the official recognition of sustainable architecture, this intention has started to be applied not for family houses 
only, but also for public buildings design. Architects E. Schleger and L. Liesler incorporated these ideas in their design of indoor swimming pools and halls. Among all of their projects abroad, a Solar collector house for Neresnica swimming pool in Zvolen (1992) (Fig. 6) has been built in Slovakia. The authors have formed their solar architecture as a combination of passive and active solar systems. The basic passive principles applied were orientation to cardinals, respect strength and direction of wind, microclimate quality, shape and layout of the building, the area of the transparent parts of the building and used materials. Equally important was the heat gain from sunlight through procured greenhouse stored in storage mass construction. Thanks to this greenhouse energy the architects managed to save about one-third of the energy demand for heating. The solar collectors for heating and hot water were designed. With the total area of 577.5 square meters they represented the largest collector area in Slovakia at that time. [8]

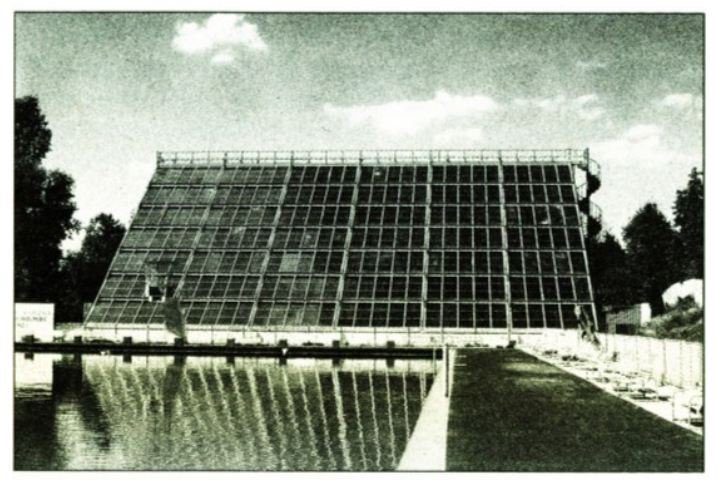

Fig. 6, Solar collector house for Neresnica swimming pool in Zvolen with the area of 577.5 square meters of solar collectors. [8] Architects E. Schleger, L. Liesler

Monitoring of energy savings was the starting point of most architectural designs in the 90s. Energy-eco-house in Hontianske Nemce (1995), designed by architect I. Hojsík as well as authors published reflections on this topic testify the importance of energy savings. Already in 1985, based on his research results at the University of Massachusetts in the United States, architect has proposed several series of energy houses and apartment buildings such as earth houses or flats applying energy efficiency in their internal zoning. The proposed experimental houses, however, managed to be tested only partially, after a self-building of a modified house from the series of earth houses. [9]

In sustainable architecture design also the formal expression and ecology of construction was emphasized. Traditional natural building materials such as wood and clay have been rediscovered. In sustainable design the economic savings, environmental impact, recyclability of the materials and the aesthetics and architectural design of buildings from natural materials have been considered. One of the first projects of experimental clay house was designed by architect H. Pifko in 1995. At a Family house in Hamuliakovo he applied all gained knowledge of the proposal of environmentally conscious architecture while following the traditional regional architecture.

Over time, sustainable architecture became more complex, relying on high-quality materials and new technologies, available information from abroad and also on domestic research results. The building of National Bank of Slovakia in Bratislava (1997-2002) (Fig. 7) designed by the architects M. Kusý and P. Paňák is an example of such an architecture . Architects inspired by structures from abroad designed the bank with an emphasis on reducing the energy consumption of the building, while using modern materials and technologies. [10] The formal expression of the building was one of the main priorities as well. This building, as the first intelligent building in Slovakia, started the design of technologically advanced buildings, that have been hiding their ingenious proposal inside. In the following years, the interest in energy-efficient houses has increased and first low-energy and passive houses have been built. 


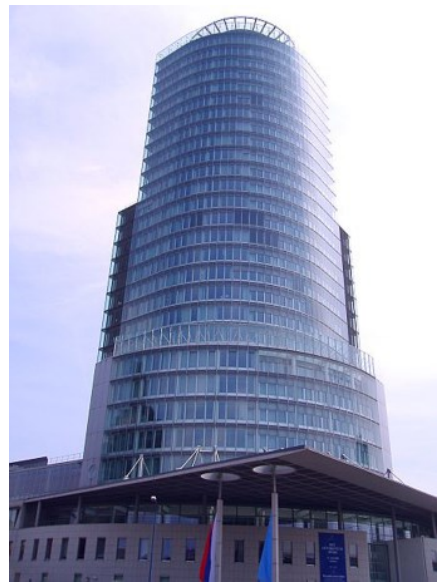

Fig. 7, National Bank of Slovakia in Bratislava, the first intelligent building in Slovakia. Architects M. Kusý, P. Paňák

\section{Standardization of Sustainable Architecture}

In a few years the sustainable architecture in Slovakia began to be perceived more intense and has become a standard in architectural design. Often, the award-winning architecture was the one designed in green quality. The Office building of Unipharma company in Bojnice serves as an example. Building designed by architect J. Keppl was awarded which the prestigious award of Slovak Architecture, Building of the Year 1999, precisely for its ecological concept. The building has been designed with the aim to reduce its energy requirements. The architect sought to achieve the environmental aspects of the building by using conventional building materials and suitable spatial concept, without implementing over-sophisticated technical equipment and technology, which are the essential elements of intelligent buildings. [11]

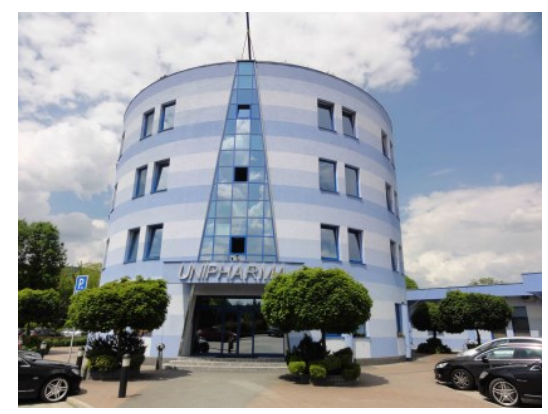

Fig. 8, Office building of Unipharma company in Bojnice, Building of the Year 1999. Architect J. Keppl

At present, sustainability in architecture is being discussed almost constantly. Conferences, standards and government regulations provide the basic framework. Various associations and organizations dealing with this issue raise awareness of people and promote the development of sustainable architecture. International green building certification systems developed already in late 1990s evaluate the complexity of building' sustainability. Constantly growing market of low-energy houses, passive or active houses, zero energy buildings or architecture of natural materials and their various combinations is the response to these impulses. Passive wooden-straw family house on the northern slope in Melčice - Lieskové from Oximoron studio is an example of energy-efficient building made of natural materials. The requirements of investor were passive house design independent of public distribution, built from ecological materials and using local resources. Overall, the house is up $90 \%$ composed of organic and renewable materials. The family house design is based mainly on passive solar gains but photovoltaic and photo thermal panels will also be installed. [12] The building was nominated to ARCH magazine Award 2013, indicating the progress of sustainable architecture. 

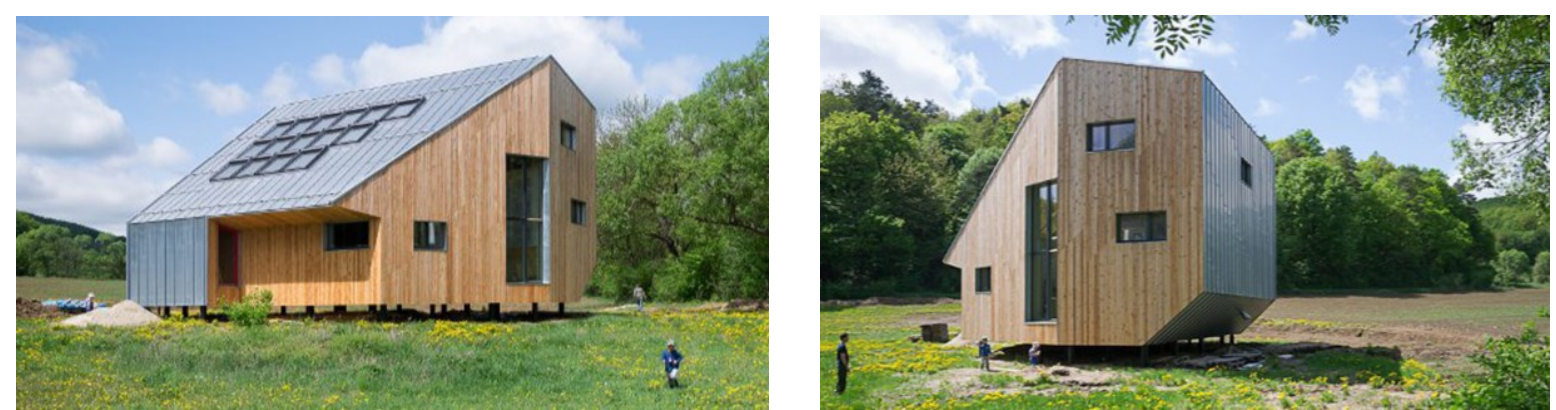

Fig. 9 Passive wooden-straw family house on the northern slope in Melčice - Lieskové. [12] Oximoron Studio (M. Šichman, B. Meluš)

\section{Summary}

Brief overview of the forty year development of sustainable architecture reflects changes in architecture on the background of social and economic events and environmental influences. The presence of sustainable architecture is miscellaneous and its future certainly promising. Low energy has already become a necessary standard. How we deal with sustainable architecture in the future, remains questionable. We have the opportunity to draw lessons from previous periods in order to achieve the current sustainable requirements, but whether we utilize it, remains equally questionable.

\section{References}

[1] J. Keppl, K. Macháčová, A. Križánková, Our 20-year Long Journey towards Meeting the Objectives of the European Strategy for Year 2020, in: Architectural Education and the Reality of the Ideal: Environmental design for innovation in the post-crisis world, Neapol, 2013, pp. 237-250.

[2] J. Keppl, Tri desat'ročia ekologického konceptu architektúry, Životné Prostredie, Vol. 34, No. 4 (2000) 178-184

[3] J. Keppl, 15 rokov výučby ekologicky motivovanej architektúry na FA STU, Architektonické listy FA STU, Vol. 11, No. 3 (2007) 105-110

[4] V. Šteffl, Nízkoenergetický obytný dom, Projekt, Vol. 346, No. 4 (1991) 16-17

[5] L. Kušnír, Experimenty zamerané na úsporu energií, Projekt, Vol. 295, No. 3 (1986) 36-39

[6] L. Kušnír, Experimentálny bytový dom vo Valticiach dostane mladšieho "brata" v Holíči, Projekt, Vol. 346, No. 4 (1991) 6-7

[7] Š. Drapčat, Solárny rodinný dom v Leviciach, Projekt, Vol. 354, No. 2 (1992) 48-49

[8] E. Schleger, L. Liesler, Solárna energia vo futurologických projektoch???, Projekt, Vol. 353, No. 1 (1991) 62-63

[9] I. Hojsík, "Energoúvahy" o energodomoch, Projekt, No. 2 (1997) 46-49

[10] V. Vojtková, Pribúda techniky i technológie - pre návrat k prirodzenému používaniu domu, Projekt, No. 1 (1997) 47-49

[11] Information on http://www.dak.sk/unipharma.html

[12] A. Salvová, Netypický pasívny dom alebo Ako sa chytá slnko (Atypical Passive House or How to Catch the Sun), Information on http:/www.stavebnictvoabyvanie.sk/ekobyvanie-energetickealternativy/1371-netypicky-pasivny-dom-alebo-ako-sa-chyta-slnko 